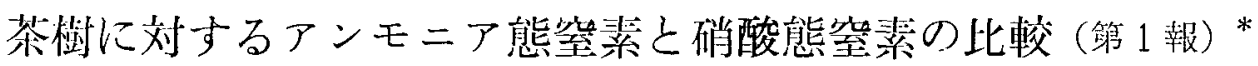 窒素 濃度の影響
}

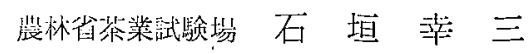

\section{Evaluation of Ammonium Nitrogen and Nitrate \\ on the Tea Plant as Nitrogen Source (Part 1)}

\author{
On the Concentration of Nitrogen
}

By Kôzô IsHigaKI

\section{1 ま がき}

作物に利用される窒素の衍態は，主としてアンモニア 態窒素 $\left(\mathrm{NH}_{4}-\mathrm{N}\right)$ と硝酸態港菜 $\left(\mathrm{NO}_{3}-\mathrm{N}\right)$ であるが, 古くからての二つの北態の学装の吸収利用については多 くの研究がある。

すなおち，KELLNER は水稻について，いずれの班態 の窒素むよく吸収されることを報告して抢り，長岡は水 稻に対して $\mathrm{NO}_{3}-\mathrm{N}$ のほうが $\mathrm{NH}_{4}-\mathrm{N}$ より藷しく㸓る ことを認めた。さらに，大工原は，水穱に対して $\mathrm{NO}_{3}-\mathrm{N}$ 怔劣る原因について考察を加えている。沙谷・佐伯ら は，各種作物を用いて，乙の両北態の窒䋕の利用につい て研究を行ない， $\mathrm{NO}_{3}-\mathrm{N}$ を好む作物と $\mathrm{NH}_{4}-\mathrm{N}$ を好む 作物纪分けて考察した。その後，春日乖・南ら゙，水稻 に対する窒絜北態について各種条件下で詳組に比较し た。

戦㣪は，多くの研究者によって，多くの作物を刘象に していろい万の任度加ら研究が行なわれ，また，総合的 な解説もなされている。最近では，重空骡 $\left({ }^{15} \mathrm{~N}\right)$ を用い た新しい研究法によって $\mathrm{NH}_{4}-\mathrm{N}$ そ $\mathrm{NO}_{22.23}-\mathrm{N}$ の作物体

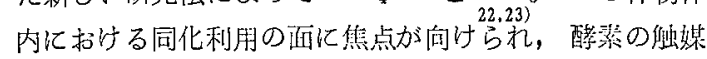
作用の研究と並行して、とれらの研劣は著しい進歩をみ せている。

茶樹化刘する $\mathrm{NH}_{4}-\mathrm{N}$ と $\mathrm{NO}_{3}-\mathrm{N}$ の比較については，

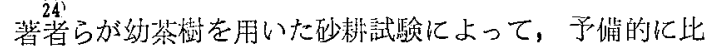
較したところ, 一般飞 $\mathrm{NH}_{4}-\mathrm{N}$ のほうが $\mathrm{NO}_{3}-\mathrm{N}$ に比 べて生沓が良好であり，かつ， $\mathrm{NO}_{3}-\mathrm{N}$ 区では柽度のク ロロシスをおこすことを認めた。さらに，培地の $\mathrm{pH} に$ よって影響されるととについても斏告した。また，土耕 試験で奻茶樹を供試して，アンモニア系窒素肥料（硫酸 アンモニア）之硝酸系空素肥料（硝酸カルシウム）の肥 効を比較したととろ，アンモ二ア系翣䒺肥料のほうが生

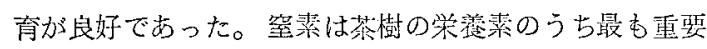

な成分であるので，窒絮の北態の比较について基濋湖に もっ上詳しく検討するてとが必要である。そてで今回, 砂耕法により, 窒装の北態を $\mathrm{NH}_{4}-\mathrm{N}$ と $\mathrm{NO}_{3}-\mathrm{N}$ とし，

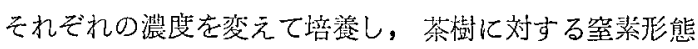
の比較䟼験を行なったのでその結果を瓣告する。

\section{2 試 験 方 法}

a/2000ワグネルポットを用いた砂料法により，培鉴液 の窒素形態を $\mathrm{NH}_{4}-\mathrm{N}$ と $\mathrm{NO}_{3}-\mathrm{N}$ とし，その濃度を $\mathrm{N}$ 上してそれぞれ，25，50，100 ppm とし，乙れ無窒装 区を加えて計 7 区の試験区を設け2 反復とした。リン酸

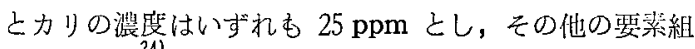
成はこ机までと同㥞にし，培養液の $\mathrm{pH}$ は 5 亿調節し た。1963年5月 1 日に紅茶用品種心゙にほまれ2 年生苗を 定植して試験を始め，1964年9月25日まで培遠した。

試験開始後しばらく均整截培を続け，11月20日初年 度の生青調查として各区の生青した玟の長さを測定して 全枝延長を算出し，生育量を比㣀した。また，新葉につ いて, 赤外線ガス分析器によって同化量と呼吸量の測 定, ワールブルグ検圧計によって䣼素力㑛（ポリフェ， 一ルオキシダーゼ力仙，および，カタラーゼ力俩） の测 定，お岾，葉分析 (無機成分含量)を行なった。ま た，1964年 4 月16日に新菜を採取して，同様化同化㯺と 呼吸量, 酵素力佂, 葉分析 (クロロフィル, 怗, デンプ ン,タンニン，および，血機成分の各含量）を行なっ た。9月25日飞試験を打ち切ってポットから茶樹を引き 扳き, 生育量（全枝延長）を測定し, 葉, 幹枝, 根の各 器官別化分けて生体重を測定し, また, 各器官別の無機 成分含量を調べた。

\section{3 成績および若察}

\section{1 生育調 査}

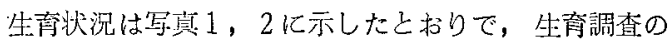

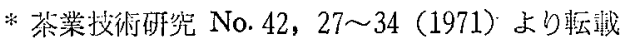



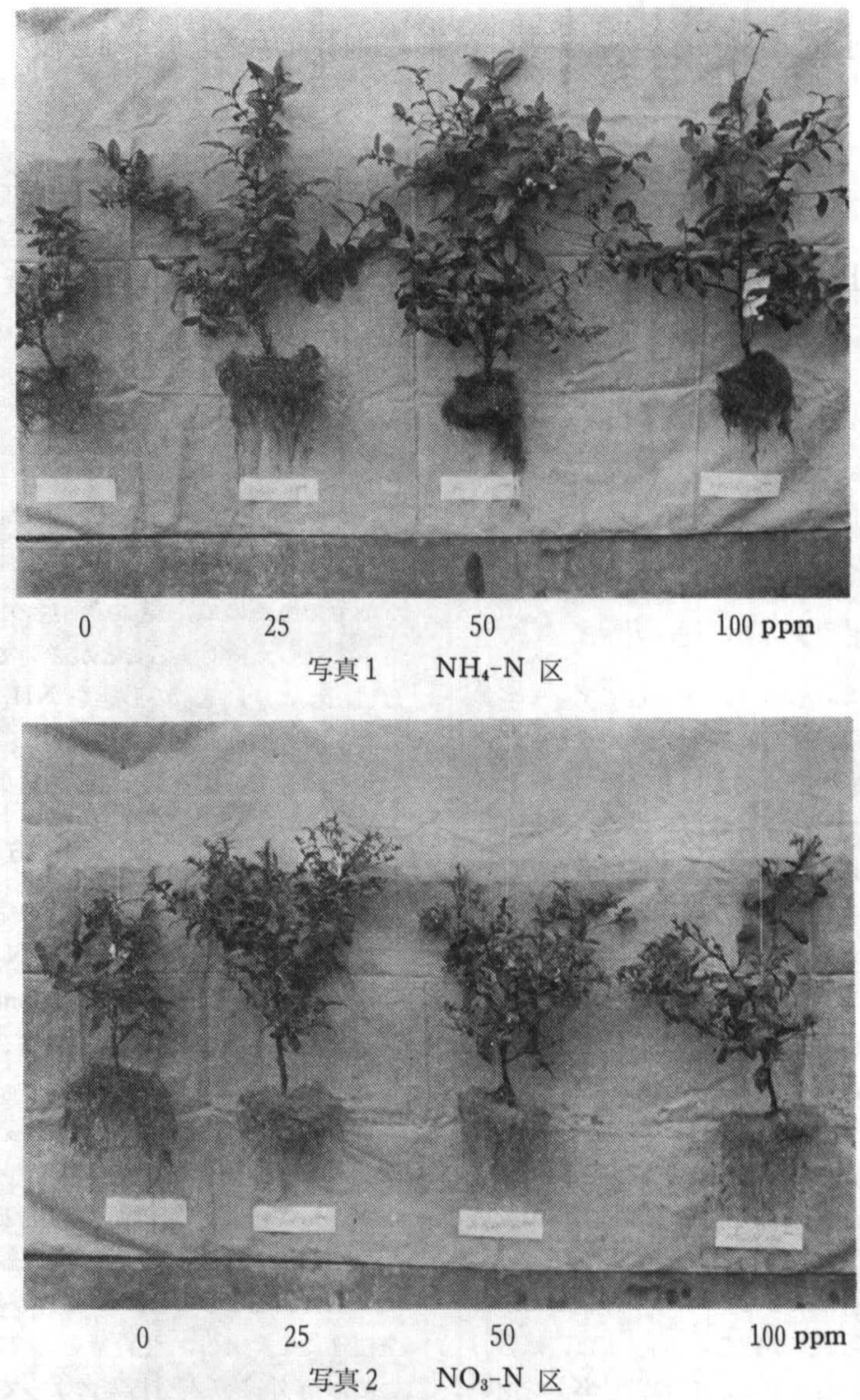

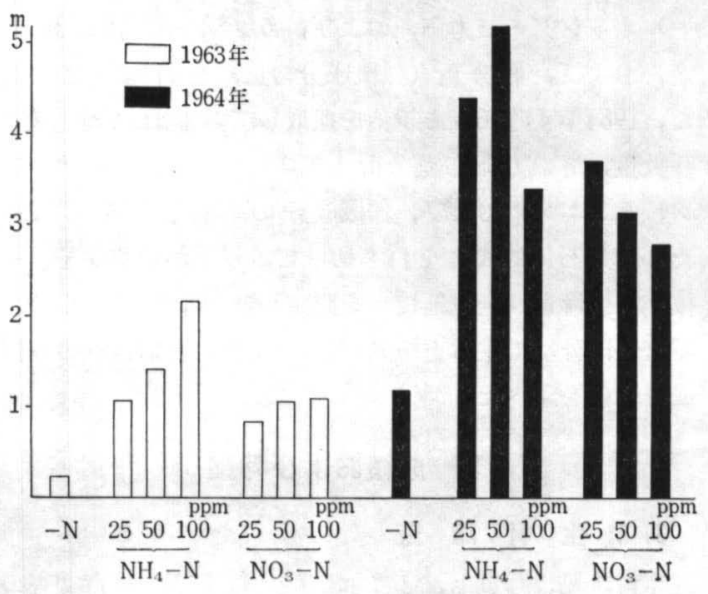

図 1 生 育 量 (全枝延長)
結果, 2 区の平均値を図 1 (生育量), 表 1 (生体重) に 示した。

生育調査の結果についてみると，無窒素区は著しく生 育が劣り，クロロシスをおこした。窒素の形態について 比較すると, 初年度では, 両形態とあ窒素濃度の増加に 伴って生育は良好となったが， その増加割合は $\mathrm{NH}_{4}-\mathrm{N}$ 区のほうが顕著であり, $\mathrm{NO}_{3}-\mathrm{N}$ 区では $50 \mathrm{ppm}$ を限度 としてやや頭打ちとなる傾向を示した。2 年目において は, $\mathrm{NH}_{4}-\mathrm{N}$ 区では $50 \mathrm{ppm}$ 区が最も良好で $100 \mathrm{ppm}$ 区はむしろ生育が劣っていた。 $\mathrm{NO}_{3}-\mathrm{N}$ 区では, $25 \mathrm{ppm}$ 区が最もよく，濃度の増加に伴って生育が劣る傾向を示 し，かつ， 50 ppm 区と 100 ppm 区のものはわずかにク ロロシスをおこした。また，いずれの形態のものも， $100 \mathrm{ppm}$ 区は著しく生育が悪かった。すなわち, $\mathrm{NH}_{4}-\mathrm{N}$, $\mathrm{NO}_{3}-\mathrm{N}$, いずれも, 初期生育は窒素濃度の増加に伴って 
表 1 生育調查（生体重）

\begin{tabular}{|c|c|c|c|c|c|c|}
\hline $\begin{array}{c}\text { 試 䄼 区 } \\
\text { No. }\end{array}$ & 窒䕀形拃 & 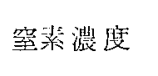 & 全生体琶 & 準 重 星 & 翰枝重星 & 根 重 量 \\
\hline 1 & 無 堂 菜 & $0^{\mathrm{ppm}}$ & $\begin{array}{r}\mathrm{g} \\
92.5^{-}\end{array}$ & 35.9 & $29.8^{\mathbf{g}}$ & $27.1^{g}$ \\
\hline 2 & \multirow{3}{*}{$\mathrm{NH}_{4}-\mathrm{N}$} & 25 & 349.0 & 118.7 & 155.0 & 75.3 \\
\hline 3 & & 50 & 398.8 & 134.5 & 186.6 & 77.7 \\
\hline 4 & & 100 & 209.5 & 90.8 & 82.3 & 36.4 \\
\hline 5 & \multirow{3}{*}{$\mathrm{NO}_{3}-\mathrm{N}$} & 25 & 212.5 & 79.9 & 95.6 & 37.1 \\
\hline 6 & & 50 & 165.6 & 66.5 & 65.2 & 33.9 \\
\hline 7 & & 100 & 146.8 & 63.6 & 54.2 & 29.0 \\
\hline
\end{tabular}

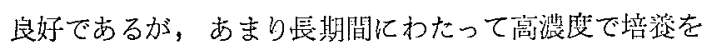

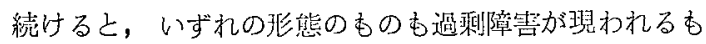
のと推繁される。

\section{2 同化量および呼吸量}

衫皮度では10月16日に，2年目においては4月16日に，

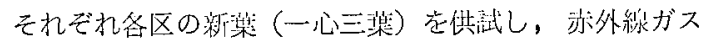

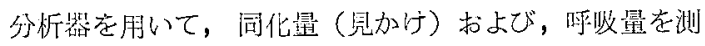
定した。とれらの絬果加ら，其の同化量（見加けの同化 量十呼吸量) を算出して図示寸ると，図2 (1963年) お 上び, 図 3 (1964年) のとおりである。

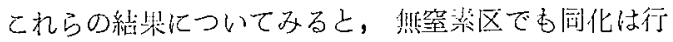
なわれているが呼呚星が少ない。窒少形態について比㷋 すると，初年度では， $\mathrm{NH}_{4}-\mathrm{N}$ 区の場合，一般に堂淡浱 度の増加に伴って同化量が增加寸る傾何がある。て机に 対して $\mathrm{NO}_{3}$-N 区では，50 ppm 区は $25 \mathrm{ppm}$ 区より多 いが, $100 \mathrm{ppm}$ 区ではむしろ減少している。呼呚望につ いてみるといずれの北態の場合も50 ppm 区のものが 最も多く，葉面櫴当たりでは $\mathrm{NH}_{4}-\mathrm{N}$ 区がわずかに多 く，乾物当たりでは $\mathrm{NO}_{3}-\mathrm{N}$ 区のほうが多い。したがっ

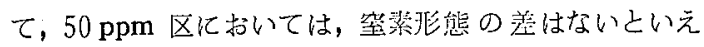
る。また， $\mathrm{NO}_{3}-\mathrm{N}$ 区の $100 \mathrm{ppm}$ 区では，きわわて少 なかった。2 年目に招いては， $\mathrm{NH}_{4}-\mathrm{N}$ 区の埸合は，一

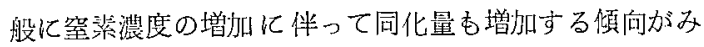
られるが，100 ppm 区ではやや頭打ちとなり，乾物 $1 \mathrm{~g}$ 当たりで示すと，むしろ $50 \mathrm{ppm}$ 区より減少している。 これに対して， $\mathrm{NO}_{3}-\mathrm{N}$ 区では，明らかな傾问はないが，

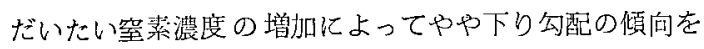
示している。呼吸量は，いずれの非態む空素の濃度の增 加に伴って堌加の傾何があるが，100 ppm 区では頭打ち の傾向が認められた。

したがって，真の同化量についてみると， $\mathrm{NH}_{4}-\mathrm{N}$ 区 では，50 ppm 区が最も多く， $\mathrm{NO}_{3}-\mathrm{N}$ 区では $25 \mathrm{ppm}$ 区 が最も多いが，全般㘬にみて $\mathrm{NH}_{4}-\mathrm{N}$ 区のほうが $\mathrm{NO}_{3}-\mathrm{N}$

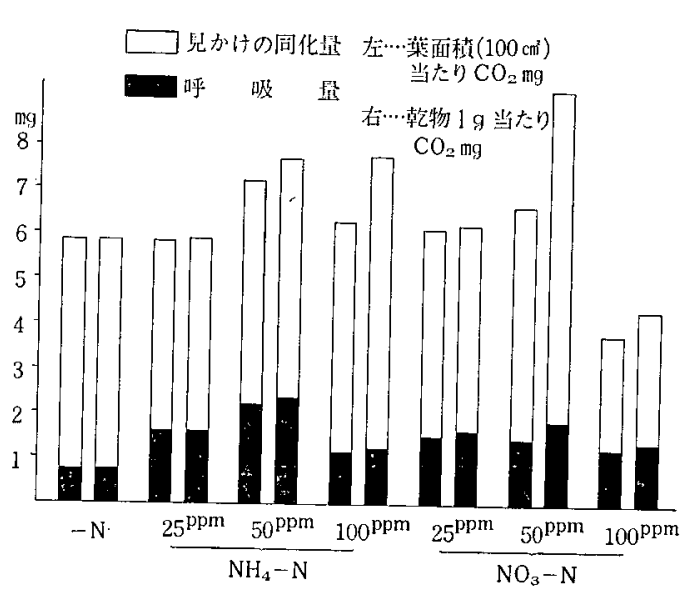

図 2 真口同化量 (1963年)

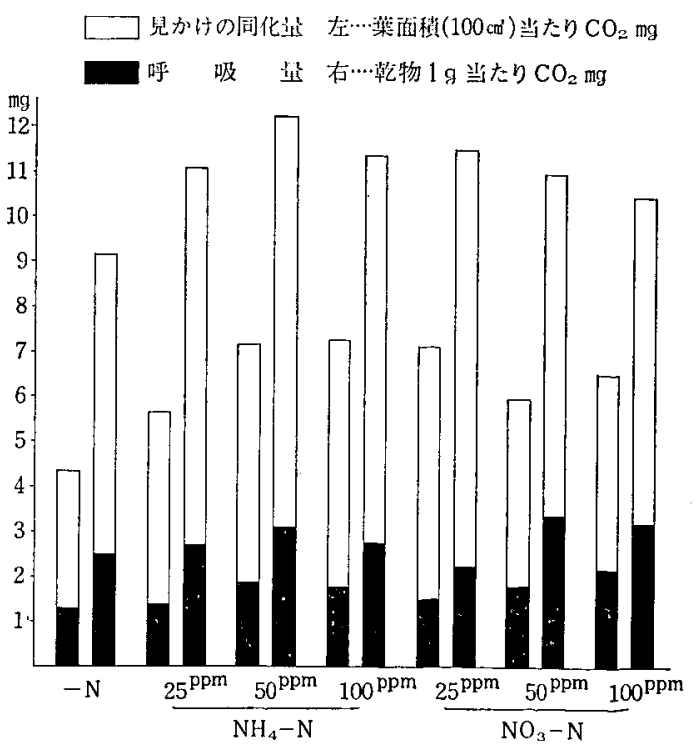

図 3 真の同化量 (1964年) 
区に比べて同化能力が大きい燬向が認められ，生育調查 の結䍒と一致した。

\section{3 醰素 力 価}

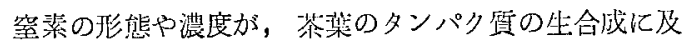

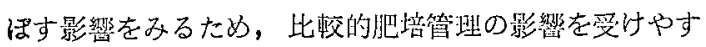
いと考えら机る銅醅奖のポリフェノールオキシダーゼ力 価と，鉄酵素のカタラーゼ力洒を比較してみた。また， ポリフェノールオキシダーゼは, 紅枩製造に火くととの

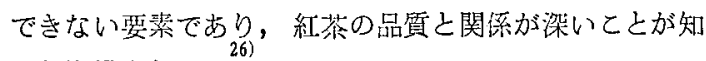
られ注目されている。

1964年 4 月16日に新葉（一心三葉）を供試し，ワール ブルグ检压計により，アセトン抽出残留物を用いて，ポ リフェノールオキシダーゼ力洒は $\mathrm{O}_{2}$ 派収量, カタラー ゼ力価は $\mathrm{O}_{2}$ 排出量を测定し, 試料 $1 \mathrm{mg}$ 当たりと, タ ンパク態窒䕀 $1 \mathrm{mg}$ 当たりで表わした。その結果は装 2 に示したとおりである。

表 2 酵菜 力仙

\begin{tabular}{|c|c|c|c|c|c|c|c|}
\hline \multirow{2}{*}{ No. } & \multirow{2}{*}{ 窒䕀形態 } & \multirow{2}{*}{ 窒䌽温度 } & \multirow{2}{*}{ 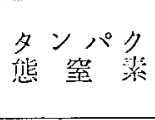 } & \multicolumn{2}{|c|}{$\begin{array}{l}\text { ポリフェノール } \\
\text { オキシダーゼ力価 }\end{array}$} & \multicolumn{2}{|c|}{ カタラーゼ力価 } \\
\hline & & & & $\begin{array}{l}\text { 械 } \\
\text { lmg当たり }\end{array}$ & N 1 mg当たり & 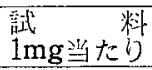 & N 1 mg当たり \\
\hline 1 & 排 窒 糸 & $0^{\mathrm{ppm}}$ & 3.46 & 67.5 & 1982 & 2.33 & 58.8 \\
\hline 2 & & 25 & 4.17 & 102.1 & 2465 & 6.28 & 150.7 \\
\hline 3 & $\mathrm{NH}_{4}-\mathrm{N}$ & 50 & 4.56 & 100.5 & 2204 & 6.22 & 136.4 \\
\hline 4 & & 100 & 5.83 & 123.6 & 2124 & 4.38 & 75.0 \\
\hline 5 & & 25 & 4.03 & 86.8 & 2154 & 4.03 & 99.9 \\
\hline 6 & $\mathrm{NO}_{3}-\mathrm{N}$ & 50 & 4.26 & 93.0 & 2182 & 4.60 & 100.0 \\
\hline 7 & & 100 & 4.29 & 120.0 & 2823 & 5.33 & 125.0 \\
\hline
\end{tabular}

注：ポリフェノールオキシダーゼ力㑛…… $\mathrm{O}_{2} \downarrow \mu l / 15^{\prime}$ カタラーゼ力洒…… $\mathrm{O}_{2} \uparrow \mu l / 3^{\prime}$

これらの絬果についてみると，アセトン抽出残留物中

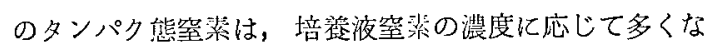
るが，その增別制合は $\mathrm{NH}_{4}-\mathrm{N}$ 区のほうが顕著であり， $\mathrm{NO}_{3}-\mathrm{N}$ 区のものは $50 \mathrm{ppm}$ 区と $100 \mathrm{ppm}$ 区 の間では

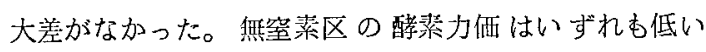
が，ポリフェノールオキシダーゼ力価のほうが顕著に少 なかった。窒菜の形態について比較すると, ポリフェノ ールオキシダーゼ力佔は， $\mathrm{NH}_{4}-\mathrm{N}$ 区のほうが $\mathrm{NO}_{3}-\mathrm{N}$ 区の屯のに比べてやや活性が望いが， $\mathrm{NO}_{3}-\mathrm{N}$ 区のほう が空素濃度の增加に伴って活性が留くなる傾向が热めら れた。カタラーゼ力価も全般的に $\mathrm{NH}_{4}-\mathrm{N}$ 区のほうが $\mathrm{NO}_{3}-\mathrm{N}$ よりも活性が高いが, $\mathrm{NH}_{4}-\mathrm{N}$ 区では $25 \mathrm{ppm}$ 区と $50 \mathrm{ppm}$ 区が最大値を示し，100 ppm 区ではかえっ て低下した。また，ポリフェノールオキシダーゼ力洒の

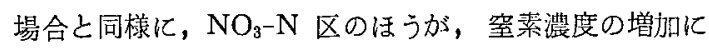
伴って高くなる傾向が認められた。

これらのことから, 䇪菜欠そ状態では, 䤃素の生合成 が押えられて活性が低くなるが，絰素を供給することに よって醉絜作用が正常愎して活性が高くなるものと思 われる。との場合，ての活性は $\mathrm{NH}_{4}-\mathrm{N}$ 区の活うが $\mathrm{NO}_{3}-\mathrm{N}$ に比べて高いということが言えそうである。し 加, 窒素が過剩の状態になると酵素活性が再び低下す
るが，その懐度は $\mathrm{NH}_{4}-\mathrm{N}$ 区と $\mathrm{NO}_{3}-\mathrm{N}$ 区とによって 潩なり，特に，力タラ一ゼ力価の場合が顕著であった。 以前にポットに上る土䉽試験で，アンモニア系窒䋕肥料 と硝酸系空素肥料の比較斌験老行なった絬果，対照区で はアンモニア系窒装肥料のほうが生育は良好であった が，過剩に施用した場合にはアンモニア系窑素肥料のほ うが過剩の害が強く現われたことを報告した。この場 合, $\mathrm{NH}_{4}-\mathrm{N}$ の過剩供給によって醉素力洒方低下し，窒 素代謝が乱れたてとも一つの原因として考えられるので はなかろうか。

\section{4 茶樹の化学成分}

1963年11月20日の新葉について㫮機成分含量を調べ， 1964年 4 月16日の新檴については,クロロフィル, 糖 (還 元糖，非還元糖），デンプンおよび，タンニンの各含量を 測定し，さらに，無機成分含量についても調べた。ま た, 試験終了後, 茶樹を器官別に分けて生体重を測定し たのち，茶葉 (成葉)，幹枝，および, 根の各器官別につ いて，それぞ机無機成分含量を調べた。その結果は，表

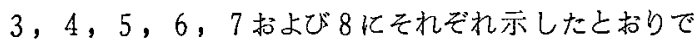
ある。な扔，陚料はいず执も2区混合して分析に供し た。クロロフィルは古谷らによる Comar の变法, 桾類 はHans 法,タンニンは岩浅らによる酒石酸鉄比色法を 
表 3 器葉の搵機成分含量 (1963年新葉)

\begin{tabular}{|c|c|c|c|c|c|c|c|c|c|c|}
\hline No. & 窒䒧形態 & 濃 度 & 全窒素 & リン 酸 & 力 リ & 石 灭 & 苦 土 & マンガン & 鉄 & $\begin{array}{l}\text { アルミ } \\
=\text { ウ }\end{array}$ \\
\hline 1 & 舤窒素 & $\begin{array}{c}\text { ppm } \\
0\end{array}$ & $\begin{array}{r}\% \% \\
2.41\end{array}$ & $\begin{array}{r}\% \\
1.74\end{array}$ & $\begin{array}{r}96 \\
2.49\end{array}$ & $\begin{array}{r}\not \% \\
0.78\end{array}$ & $\begin{array}{r}96 \\
0.19\end{array}$ & $\begin{array}{r}\% \\
0.034\end{array}$ & $\begin{array}{r}\% 6 \\
0.067\end{array}$ & $\begin{array}{r}86 \\
0.100\end{array}$ \\
\hline 2 & & 25 & 3.31 & 0.67 & 1.46 & 1.11 & 0.17 & 0.177 & 0.036 & 0.103 \\
\hline 3 & $\mathrm{NH}_{4}-\mathrm{N}$ & 50 & 3.65 & 0.65 & 1.37 & 1.09 & 0.16 & 0.201 & 0.035 & 0.192 \\
\hline 4 & & 100 & 4.04 & 0.67 & 0.97 & 0.63 & 0.14 & 0.113 & 0.033 & 0.194 \\
\hline 5 & & 25 & 3.43 & 0.62 & 1.40 & 1.67 & 0.22 & 0.024 & 0.034 & 0.085 \\
\hline 6 & $\mathrm{NO}_{3}-\mathrm{N}$ & 50 & 3.85 & 0.59 & 1.28 & 2.18 & 0.22 & 0.022 & 0.031 & 0.085 \\
\hline 7 & & 100 & 4.00 & 0.59 & 1.24 & 2.92 & 0.19 & 0.019 & 0.028 & 0.085 \\
\hline
\end{tabular}

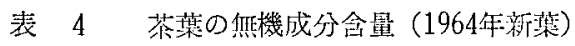

\begin{tabular}{|c|c|c|c|c|c|c|c|c|c|c|}
\hline No. & 窒素形態 & 濃 度 & 全窒素 & リン 酸 & 力 & 石 灰 & 苦 土 & マンガン & 鉄 & $\begin{array}{l}\text { アル } \\
=\text { ウ }\end{array}$ \\
\hline 1 & 無窒素 & $\underset{0}{\mathrm{ppm}}$ & $\begin{array}{r}\% \\
2.98\end{array}$ & $\begin{array}{r}\% 6 \\
1.22\end{array}$ & $\begin{array}{r}96 \\
2.85\end{array}$ & $\begin{array}{r}o 6 \\
0.72\end{array}$ & $\begin{array}{r}96 \\
0.54\end{array}$ & $\begin{array}{r}96 \\
0.049\end{array}$ & $\begin{array}{r}96 \\
0.052\end{array}$ & $\begin{array}{r}96 \\
0.108\end{array}$ \\
\hline 2 & & 25 & 3.56 & 0.87 & 2.40 & 0.72 & 0.40 & $0.123^{\circ}$ & 0.050 & 0.123 \\
\hline 3 & $\mathrm{NH}_{4}-\mathrm{N}$ & 50 & 3.89 & 0.86 & 2.28 & 0.56 & 0.34 & 0.129 & 0.054 & 0.128 \\
\hline 4 & & 100 & 4.07 & 0.87 & 2.03 & 0.56 & 0.28 & 0.062 & 0.056 & 0.132 \\
\hline 5 & & 25 & 3.87 & 0.85 & 2.35 & 1.12 & 0.50 & 0.045 & 0.047 & 0.087 \\
\hline 6 & $\mathrm{NO}_{3}-\mathrm{N}$ & 50 & 3.90 & 0.85 & 2.27 & 1.34 & 0.42 & 0.032 & 0.046 & 0.085 \\
\hline 7 & & 100 & 4.07 & 0.87 & 2.14 & 1.57 & 0.36 & 0.041 & 0.042 & 0.087 \\
\hline
\end{tabular}

表 5 䒩葉のクロロフィル, 糖, デンプン, タンニンの各含量 (1964年新集)

\begin{tabular}{|c|c|c|c|c|c|c|c|c|}
\hline \multirow{2}{*}{ No. } & \multirow{2}{*}{ 穻素形態 } & \multirow{2}{*}{ 漂 } & \multicolumn{2}{|c|}{ クロロフィル } & \multicolumn{2}{|c|}{ 糖 } & \multirow{2}{*}{ デンプン } & \multirow{2}{*}{ タンニン } \\
\hline & & & a & $\mathrm{b}$ & 還 元 糖 & 非還元糖 & & \\
\hline 1 & 無窒 素 & $\underset{0}{\mathrm{ppm}}$ & $\begin{array}{r}\% 6 \\
0.079\end{array}$ & $\begin{array}{r}\% 6 \\
0.035\end{array}$ & $\begin{array}{r}06 \\
1.61\end{array}$ & $\begin{array}{r}\% \\
2.27\end{array}$ & $\begin{array}{r}\% \\
2.20\end{array}$ & $\begin{array}{r}\% \% \\
4.33\end{array}$ \\
\hline 2 & & 25 & 0.144 & 0.067 & 1.46 & 2.56 & 2.58 & 4.44 \\
\hline 3 & $\mathrm{NH}_{4}-\mathrm{N}$ & 50 & 0.175 & 0.077 & 2.25 & 4.08 & 1.59 & 4.67 \\
\hline 4 & & 100 & 0.189 & 0.082 & 2.65 & 5.40 & 1.38 & 5.06 \\
\hline 5 & & 25 & 0.133 & 0.062 & 1.16 & 3.41 & 1.97 & 4.67 \\
\hline 6 & $\mathrm{NO}_{3}-\mathrm{N}$ & 50 & 0.132 & 0.059 & 1.65 & 5.57 & 1.40 & 4.00 \\
\hline 7 & & 100 & 0.130 & 0.054 & 1.47 & 4.38 & 2.09 & 3.80 \\
\hline
\end{tabular}


茶業研究郝告

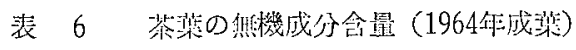

\begin{tabular}{|c|c|c|c|c|c|c|c|c|c|c|}
\hline No. & 窒素形態 & 濃 度 & 全䇪 素 & リン 酸 & カ リ & 石 乍 & 苦 土 & マンガン & 鉄 & $\begin{array}{l}\text { ア ル } \\
\text { 品 }\end{array}$ \\
\hline 1 & 無 窒 素 & ppm & $\begin{array}{r}96 \\
1.89\end{array}$ & $\begin{array}{r}96 \\
1.55\end{array}$ & $\begin{array}{l}.06 \\
3.17\end{array}$ & $\begin{array}{r}\% \\
1.08\end{array}$ & $\begin{array}{r}\% \\
0.46\end{array}$ & $\begin{array}{r}96 \\
0.019\end{array}$ & $\begin{array}{r}\% \% \\
0.052\end{array}$ & $\begin{array}{r}\% 6 \\
0.133\end{array}$ \\
\hline 2 & & 25 & 2.21 & 0.58 & 1.87 & 1.31 & 0.39 & 0.077 & 0.064 & 0.163 \\
\hline 3 & $\mathrm{NH}_{4}-\mathrm{N}$ & 50 & 3.06 & 0.54 & 1.50 & 0.88 & 0.39 & 0.280 & 0.069 & 0.168 \\
\hline 4 & & 100 & 4.46 & 0.55 & 1.40 & 0.38 & 0.38 & 0.107 & 0.078 & 0.168 \\
\hline 5 & & 25 & 2.68 & 0.57 & 1.76 & 3.06 & 0.40 & 0.032 & 0.071 & 0.081 \\
\hline 6 & $\mathrm{NO}_{3}-\mathrm{N}$ & 50 & 2.69 & 0.52 & 1.33 & 3.85 & 0.40 & 0.028 & 0.064 & 0.073 \\
\hline 7 & & 100 & 2.68 & 0.58 & 1.28 & 4.34 & 0.39 & 0.042 & 0.063 & 0.077 \\
\hline
\end{tabular}

表 7 筷枝の無機成分含量

\begin{tabular}{|c|c|c|c|c|c|c|c|c|c|c|}
\hline No. & 窒素形態 & 濃 度 & 全窒莎 & リン 酸 & 力 リ & 石 灰 & 苦 \pm & マンガン & 錭 & $\begin{array}{l}\text { アル } \\
= \\
=\end{array}$ \\
\hline 1 & 無 窒素 & ppm & $\begin{array}{r}96 \\
1.09\end{array}$ & $\begin{array}{r}\% 6 \\
0.13\end{array}$ & $\begin{array}{l}\% 6 \\
0.74\end{array}$ & $\begin{array}{l}\% 6 \\
0.62\end{array}$ & $\begin{array}{r}\% 6 \\
0.39\end{array}$ & $\begin{array}{r}\% \% \\
0.012\end{array}$ & $\begin{array}{r}\% \% \\
0.015\end{array}$ & $\begin{array}{l}.06 \\
0.14\end{array}$ \\
\hline 2 & & 25 & 1.83 & 0.12 & 0.65 & 0.77 & 0.39 & 0.029 & 0.021 & 0.13 \\
\hline 3 & $\mathrm{NH}_{4}-\mathrm{N}$ & 50 & 1.94 & 0.12 & 0.60 & 0.76 & 0.28 & 0.035 & 0.031 & 0.15 \\
\hline 4 & & 100 & 2.06 & 0.14 & 0.60 & 0.74 & 0.12 & 0.019 & 0.043 & 0.17 \\
\hline 5 & & 25 & 1.83 & 0.16 & 0.90 & 1.69 & 0.39 & 0.018 & 0.043 & 0.12 \\
\hline 6 & $\mathrm{NO}_{3}-\mathrm{N}$ & 50 & 1.86 & 0.20 & 0.82 & 1.97 & 0.38 & 0.010 & 0.035 & 0.11 \\
\hline 7 & & 100 & 1.92 & 0.21 & 0.75 & 2.53 & 0.37 & 0.017 & 0.025 & 0.14 \\
\hline
\end{tabular}

表 8 根の䑤機成分含量

\begin{tabular}{|c|c|c|c|c|c|c|c|c|c|c|}
\hline No. & 窒弥形態 & 濃 度 & 全堂菜 & リン 酸 & 力 リ & 石 灰 & 苦 土 & マンガン & 鉄 & $\begin{array}{l}\text { アル } \\
=\text { ウ }\end{array}$ \\
\hline 1 & 無窒素 & ppm & 1.96 & $\begin{array}{r}96 \\
0.44\end{array}$ & $\begin{array}{r}96 \\
2.42\end{array}$ & $\begin{array}{r}96 \\
0.54\end{array}$ & $\begin{array}{r}\% 6 \\
0.19\end{array}$ & $\begin{array}{r}96 \\
0.041\end{array}$ & $\begin{array}{r}\% \% \\
0.102\end{array}$ & $\begin{array}{r}\% \\
0.49\end{array}$ \\
\hline 2 & & 25 & 1.37 & 0.49 & 1.96 & 0.36 & 0.34 & 0.023 & 0.887 & 1.37 \\
\hline 3 & $\mathrm{NH}_{4}-\mathrm{N}$ & 50 & 1.52 & 0.48 & 1.79 & 0.34 & 0.32 & 0.026 & 1.823 & 2.11 \\
\hline 4 & & 100 & 1.57 & 0.48 & 0.82 & 0.30 & 0.16 & 0.016 & 2.753 & 2.80 \\
\hline 5 & & 25 & 1.43 & 0.56 & 3.04 & 0.66 & 0.34 & 0.061 & 0.189 & 0.39 \\
\hline 6 & $\mathrm{NO}_{3}-\mathrm{N}$ & 50 & 1.49 & 0.57 & 2.96 & 0.88 & 0.32 & 0.065 & 0.177 & 0.43 \\
\hline 7 & & 100 & 1.57 & 0.49 & 2.82 & 1.04 & 0.26 & 0.068 & 0.132 & 0.35 \\
\hline
\end{tabular}


それぞれ用いて定量した。

これらの結果についてみると，窒素含量はいずれの部 分屯紫素濃度の増加化伴って增加するが， その增加割合 は $\mathrm{NH}_{4}-\mathrm{N}$ 区のほうが著しかった。その他の成分之の関 係についてみると, カリ含量は, 窒菜濃度の増加に伴っ て減少し拮抗作用が認められたが，乙の傾向は $\mathrm{NH}_{\mathbf{4}}-\mathrm{N}$ 区のはうが顕著であった。石灰含量は， $\mathrm{NH}_{4}-\mathrm{N}$ 区では

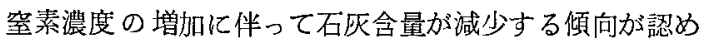
られた。とれに対して， $\mathrm{NO}_{3}-\mathrm{N}$ 区のものは逆に窒䒺渃 度の增加に伴って石灰含量が増加したが，乙れは培養液 の $\mathrm{NO}_{3}-\mathrm{N}$ の窒素源として硝酸カルシウムを用いたため であると考えられる。しかし，供給量の割にはそれはど 石灰を吸収していない。苦土念量は，いずれの非態も， いずれの部分む，堂素濃度の增加に伴ってわずかに減少 する傾向があるが，その減少割合は根の場合が比較的大 きかった。マンガン含量は，全般的に地上部 (樂, 幹枝) では $\mathrm{NH}_{4}-\mathrm{N}$ 区のあのが $\mathrm{NO}_{3}-\mathrm{N}$ 区のむのに比べて多 いが，特に葉では顕著であった。しかし，根では逆に $\mathrm{NO}_{3}-\mathrm{N}$ 区のむのが $\mathrm{NH}_{4}-\mathrm{N}$ 区のものに比べて多かっ た。䇪素濃度との関係についてみると， $\mathrm{NH}_{4}-\mathrm{N}$ 区では， いずれの部分も空素濃度 $50 \mathrm{ppm}$ 区のものが最大值を示 し，100 ppm 区では逆にその含量が減少した。 $\mathrm{NO}_{3}-\mathrm{N}$ 区では音䒺濃度との関係明らかではなかった。アルミ ニウム含量は，いずれの部分む $\mathrm{NH}_{4}-\mathrm{N}$ 区のあのが多 く，また， $\mathrm{NH}_{4}-\mathrm{N}$ 区では窒素濃度の增加に伴ってその 含量が增加したが，乙の傾问は特に根において顕著で あった。鉄含量は，地上部では大差がないが，根では $\mathrm{NH}_{4}-\mathrm{N}$ 区のあのが $\mathrm{NO}_{3}-\mathrm{N}$ 区のあのに比べて多加。 た。また， $\mathrm{NH}_{4}-\mathrm{N}$ 区では窒素濃度の增加に伴って鉄會

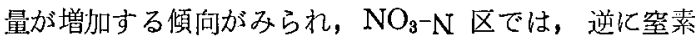
濃度の増加に伴って減少したが，乙の傾问は根において 顕著であった。

クロロフィル合量は，クロロシスをおこした無窒素区 では著しく少ないが，窒菜形態で比較すると，全般的に $\mathrm{NH}_{4}-\mathrm{N}$ 区のほうが, $\mathrm{NO}_{3}-\mathrm{N}$ 区に比べて多かった。ま た，いずれの窒素形態においても，窒素濃度が增加する とクロロフィル含量も多くなるが，50 ppm 区と $100 \mathrm{ppm}$ 区では大差がなかった。

糖含量は，無空素区でもかなり含まれているが，全般 的に，還元糖含量は $\mathrm{NH}_{-4} \mathrm{~N}$ 区のあのが多く，非還元糖 含量は $\mathrm{NO}_{3}-\mathrm{N}$ 区のものが多い傾向が認められた。また， $\mathrm{NH}_{4}-\mathrm{N}$ 区では，還元糖，非還元糖，いずれす $50 \mathrm{ppm}$ 区のものが最大值を示し，100 ppm 区ではわずか纪減少

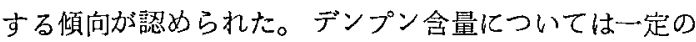
傾向がなかった。

タンニン含量は，全般的に $\mathrm{NH}_{4}-\mathrm{N}$ 区の活うが $\mathrm{NO}_{3}-\mathrm{N}$ のものに比べて多かった， $\mathrm{NH}_{4}-\mathrm{N}$ 区では，窒素濃度の 増加に伴ってタンニン含量が増加し， $\mathrm{NO}_{3}-\mathrm{N}$ 区では，
逆に窒熬濃度の增加に伴って減少する傾局がるれ，と れまでの結果と一致した。

タンニン含量は一般に少ないが，ガラス空内で栽培し た場合，これまでの武験の分析結果も同様に少なかった が，特殊条件下に長期間置かれたため，光線その他の影 䏮を受けたのではないかと考えられる。

\section{4 要約}

砂耕法によって，茶樹の生育と化学成分に及ぼす $\mathrm{NH}_{4}-\mathrm{N}$ と $\mathrm{NO}_{3}-\mathrm{N}$ の比較試験を行なった。すなわち， 1963年 5 月加ら1964年 9 月まで， 心゙にほま机 2 年生苗を 供試し，雨形態と屯，窒素濃度をそれぞれ，25，50，100

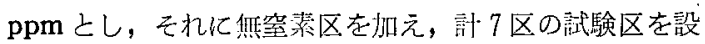

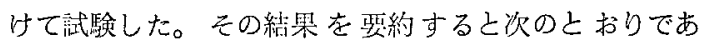
る。

1. 生育は, 全般的比 $\mathrm{NH}_{4}-\mathrm{N}$ 区のほうが $\mathrm{NO}_{3}-\mathrm{N}$ 区 に比べて良好であった。初年度は，いずれの形態屯窒素 浱度の增加に伴って生育がよかったが，2 年目ではいず れの形態も，濃度の滈い区は生育が悪くなった。

2. 同化量捄上び呼吸量は，全般的に $\mathrm{NH}_{4}-\mathrm{N}$ 区のほ うが $\mathrm{NO}_{3}-\mathrm{N}$ 区に比べて多かった。

3. 䣼素力価として，ポリフェノールオキシダーゼ 力価上カタラーゼ力洒を調べたが，いずれも全般的に $\mathrm{NH}_{4}-\mathrm{N}$ 区のほうが $\mathrm{NO}_{3}-\mathrm{N}$ 区に比べて高加た。

4. 茶樹の全空素會量は, $\mathrm{NH}_{4}-\mathrm{N}$ 区のほうか, $\mathrm{NO}_{3}-\mathrm{N}$

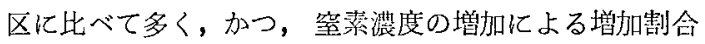
屯高汃っ。

5. 低機成分の吸收についてみると，荎菜の形態によ

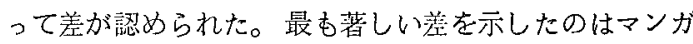
ンとアルミニウムで，いずれもその念量は $\mathrm{NH}_{4}-\mathrm{N}$ 区の ほうが $\mathrm{NO}_{3}-\mathrm{N}$ 区に比べて著しく多かった。カリ会量は 窒素濃度の增加に伴って減少したが，その減少割合は $\mathrm{NH}_{4}-\mathrm{N}$ 区のほうが高加った。 $\mathrm{NH}_{4}-\mathrm{N}$ 区における石灰 含量は，窒素旅度の增扣に伴って減少した。苦土含量は いずれの形態の場合も，窒素濃度の増加に伴って減少し た。

6. クロロフィル含量は $\mathrm{NH}_{4}-\mathrm{N}$ 区のほうが $\mathrm{NO}_{3}-\mathrm{N}$ 区のむのに比べて多かった。

7. 還元糖含量は $\mathrm{NH}_{4}-\mathrm{N}$ 区のほうが多く，非還元糖 は逆に $\mathrm{NO}_{3}-\mathrm{N}$ 区のほうが多かった。

8. タンニン含量は全般的に $\mathrm{NH}_{4}-\mathrm{N}$ 区のほうが多か った。また, $\mathrm{NH}_{4}-\mathrm{N}$ 区では䇪素濃度の增加に伴ってタ ソニン含量が増加したが， $\mathrm{NO}_{3}-\mathrm{N}$ 区では，逆に，窒素 濃度の增加に伴って減少した。

本研究を行なうにあたり，御指導をいただいた当場， 河合部長，同化，呼吸の実験卸協力をいただいたもと

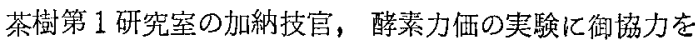




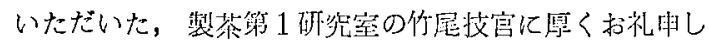
あげる。

\section{5 参 考 文 献}

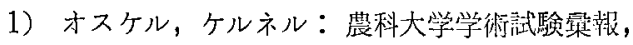
No. 1, 297 (1894).

2) Nagaoka, M.: Bull. Coll. Agr. Tokyo No. 6, 285 (1904),

3) Daikuhara, G. and J. Iseki : Bull. Imp. Centr. Agr. Exp. Stat. Japan, No. 1, 9 (1907).

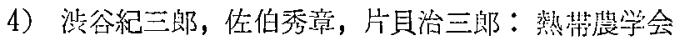
誌, No. 7, 183, 227 (1935).

5）春日井新一郎, 南 礼藏: 土肥誌，5，51(1931)。

6）佐伯唀章，伊沢悟郎：土肥誌，22－264 (1951).

7）石塚喜明，尾形昭冕：土肥誌，26，151 (1955).

8）石塚喜明，尾形炤冕：土肥誌，28，5(1957).

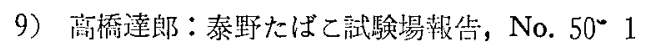
(1961).

10）藤原彰夫, 大平幸次：土肥赫，30，162，230 (1959).

11）石塚喜朋, 高岸秀次䬦：土肥誌，32，613 (1961).

12）石琭喜明, 高岸秀次郎：土肥誌，33，32(1962).

13）吉田大輔：土把誌，33，231 (1962).

14）伊沢悟郎：兵西農科大学紀要, No. 12, 1 (1962).

15）原田登五郎, 高木 浩: 土肥誌，35，181 (1964).

16）尾形炤逸：土肥誌，34，313，318(1963).

17) 尾形昭逸：土肥誌，36，259 (1965).

18）羽生 坭：栃木農試報，No. 9, 31 (1965).

19）安藤 奨: 土肥誌，36，343 (1965).

20）大沢孝也：園学誌，31，43 (1962).

21）三井進午, 熊沢喜久傩, 矢崎仁也：土肥誌， 39 , 37 (1968).

22) Yatazawa, M., K. Furuhashi, N. Kurihara, and Y. ONISHI : Soc. Sci. Soil. Manure Japan, 14, 85 (1968).

23) Yoshida, D. : Soc. Sci. Soil Manure Japan, 15, 113 (1969).

24）河合惣吾, 石垣幸三, 高柳博次: 東海近畿農試研 報(茶), No. 8, 185 (1961).

25）河合惣吾, 石垣幸三，高楖博次：茶技研，No. 27, 16 (1963).

26）竹尾忠一：茶試研報, No. 5, 1 (1969).

27）古谷弘三, 鳥井秀一：茶技研, No. 16, 32 (1957).

28）岩浅 潔, 鳥井秀一：茶技研, No. 26, 87 (1962).

29）石垣幸三，高柳博次：茶技研, No. 32, 49(1966).

\section{Summary}

The evaluation of $\mathrm{NH}_{4}-\mathrm{N}$ and $\mathrm{NO}_{3}-\mathrm{N}$ as nitrogen source on the tea plant which supplied in media containning 25, 50, $100 \mathrm{ppm}$. of nitrogen respectively was investigated from 1963 to 1964 by sand culture method. The results obtained were summarized as follows.

1. Generally, the tea plant supplied with $\mathrm{NH}_{4}-\mathrm{N}$ showed better growth than that with $\mathrm{NO}_{3}-\mathrm{N}$. The growth of the tea plant increased according to the amount of nitrogen sources in the first year, but that decreased in high concentration next year.

2. Nitrogen content in the tea plant supplied with $\mathrm{NH}_{4}-\mathrm{N}$ was higher than that with $\mathrm{NO}_{3}-$ $\mathrm{N}$, and increased both according to the amount of nitrogen.

3. Potassium content of the tea plant cultured with $\mathrm{NH}_{4}-\mathrm{N}$ showed lower than that with $\mathrm{NO}_{3}-\mathrm{N}$. Calcium content of the tea plant in $\mathrm{NH}_{4}-\mathrm{N}$ plot decreased according to the amount of nitrogen. Magnecium content of the tea plant cultured with both nitrogen sources decreased according to the amount of nitrogen.

4. Polyphenol oxidase activity and catalase activity of the tea leaves cultured with $\mathrm{NH}_{4}-\mathrm{N}$ showed higher than that with $\mathrm{NO}_{3}-\mathrm{N}$.

5 . There was general tendency that assimilative power and respiratory activity of the tea leaves cultured with $\mathrm{NH}_{4}-\mathrm{N}$ showed higher levels than that with $\mathrm{NO}_{3}-\mathrm{N}$.

6. Chlorophyll content of the tea leaves cultured with $\mathrm{NH}_{4}-\mathrm{N}$ was more than that with $\mathrm{NO}_{3}-\mathrm{N}$.

7. Tannin content of the tea leaves cultured with $\mathrm{NH}_{4}-\mathrm{N}$ showed higher than that with $\mathrm{NO}_{3}-\mathrm{N}$. And tannin content of the tea leaves increased according to the amount of $\mathrm{NH}_{4}-\mathrm{N}$ but decreased by $\mathrm{NO}_{3}-\mathrm{N}$.

(Dec., 21, 1970) 